\title{
The Vision of Agri-Environmental Sustainability in Bangladesh: How the Policies, Strategies and Institutions Delivered?
}

\author{
Ranjan Roy ${ }^{1,2,3 *}$, Ngai Weng Chan ${ }^{1}$, Takehiko Uemura ${ }^{2}$, Hidefumi Imura ${ }^{2}$ \\ ${ }^{1}$ School of Humanities, Universiti Sains Malaysia, Penang, Malaysia; ${ }^{2}$ Global Cooperation Institute (GCI), Yokohama City Univer- \\ sity, Yokohama, Japan; ${ }^{3}$ Faculty of Agriculture, Sher-e-Bangla Agricultural University, Dhaka, Bangladesh. \\ Email: *ranjansau@yahoo.com
}

Received June $16^{\text {th }}, 2013$; revised July $17^{\text {th }}, 2013$; accepted August $11^{\text {th }}, 2013$

Copyright (C) 2013 Ranjan Roy et al. This is an open access article distributed under the Creative Commons Attribution License, which permits unrestricted use, distribution, and reproduction in any medium, provided the original work is properly cited.

\begin{abstract}
Agriculture and environmental change are tightly interconnected in ways that require active roles of policy, strategy, and institution for the promotion of sustainable agriculture development. To explore this issue, this study addresses two questions 1) to what extent is environmental integration reflected in policies, strategies, and institutions? And 2) how do these policies, strategies, and institutions turn ambitions into actions? By adopting two frameworks developed by the OECD and the European Environment Agency as well as critically reviewing policy documents and conducting the key informant interviews, the results revealed that most of the policies and strategies integrated the environmental issue and had stipulated action plans and governance structure for implementation. The results also found that institutions marginally integrated the environmental concerns and faced several problems that hindered turning ambitions into actions. Overall, although policy instruments were good, the vision of sustainability was in difficulty to actualizing into action due to weak institutional setup. This study highlights the interdependence between the dimensions of policy implement tation process. Policy implications should emphasize enhancing institutional capacity, revamping agricultural advisory services, and empowering Bangladesh Agricultural Research Council (BARC) to translate the vision of agri-environmental sustainability into action.
\end{abstract}

Keywords: Policy; Strategy; Institution; Development; Sustainable Agriculture; Bangladesh

\section{Introduction}

The economy of Bangladesh is largely dependent on the performance of agriculture, which is dominated by crop production that presently accounts for about two-third of the sectoral value-added. It contributes to the largest share (19\%) of GDP (FY 2010-2011) and employs about $50 \%$ of the country's labor force [1]. Bangladesh's agriculture has made laudable progress over the period, for instance, the total rice production has increased by $243 \%$ over the last 40 years [2]. This development is primarily characterized by the introduction of high-yielding crop varieties, the evolution of irrigation, and the adoption of external-inputs-based farming approaches [3]. It is recognized that the progress in agricultural productivity comes at the cost of environmental goods and services. Research results [4,5] have indicated that the total costs in terms of declined valuable natural resources, e.g. bio-

* Corresponding author. diversity are too great for the world to bear.

In general, environmental sustainability, and particularly agri-environmental sustainability is a matter of great concern of policy makers along with poverty alleviation. The issue of agri-environmental sustainability has been significantly reflected in key governmental documents, namely Vision 2021 [6], Agricultural Research Vision 2030 and Beyond [7], and the Sixth Five-Year Plan (2011-2015) [1]. Intense pollution pressures are the primary reason for the environmental problems, which have been accompanied by the unique geographical location (i.e., Himalaya to the north and Bay of Bengal to the south) and unplanned industrialization and urbanization. Similarly, several other factors are responsible for the agri-environmental unsustainability, specifically 1) ricebased monoculture that pushes out non-cereal crops, e.g. pulse and oilseed; 2) excessive use of agro-chemicals in order to produce more crops to fulfill the population's needs; 3) traditional farming practices devoid of modern 
cultivation knowledge and technologies; and 4) lack of grower's awareness, which is largely the result of poor support and services from the public institutions. Moreover, the impact of environment problems has been reinforced by the recent impact of climate change in the form of increasing extreme climatic events such as floods, droughts, and cyclones, which are currently collectively responsible for the loss of $1.5 \%$ of the country's GDP [8]. In our view, agri-environmental sustainability refers to applying environmentally non-degrading farming practices that conserves and improves natural resources to keep the capacity of agricultural systems for maintaining it indefinitely.

A raft of studies [8-13] has enunciated that the present agricultural systems are not environmentally sound. Consistent with the results obtained by the individual researchers, the ADB [14] and the World Bank [15] have identified the key determinants of environmental degradation, and indicated the necessary measures of governance. ADB found that agrochemicals are the second main source of water pollution. Taking the prevailing situation into account, the Government of Bangladesh (GoB) has taken several initiatives, for example, signing and ratifying Multilateral Environmental Agreements and Strategies such as the Kyoto Protocol. Global climate change advocacy and action by the government was recognized as global "best practice" for preparing the "National Climate Change Strategy and Action Plan" adopted prior to the Copenhagen Summit. Pursuing sustainable development (SD) has become a constitutional obligation of the GoB, as Article 18A of the "Constitution" articulates that the "Protection and Improvement of Environment and Biodiversity" of the country. As a part of planning and management, the government institutions, particularly ministries are working on the environmental issues and have formulated a considerable number of policies, strategies, rules, regulations, and acts (Table 1) for guiding resources management as well as promoting socioeconomic development.
The concept of SD is multi-dimensional. The pursuit of SD, therefore, requires dealing of numerous aspects of the environment, society, and economics. Two issues have received much attention of researchers [16]: environmental integration or environmental policy integration (EPI) and the clarification of how to turn ambitions into actions of policies, strategies, and institutions. Hák et al. [17] reported that addressing the question of how to turn ambitions into actions for the promotion of SD is an important challenge. Adequate research on the above-mentioned two issues is scarce in the literature. Mandal [18] reviews only the policies and provides a general overview. Similarly, Agricultural Sector Review [19] investigates a good amount of policy instruments, but the issue of agri-environmental sustainability does not receive much attention. Both studies gathered fragmented information in terms of what we are exploring. In the present study, we have fulfilled these research gaps. Pointedly, this study will be guided by the following two research questions:

- To what extent is EPI reflected in policies, strategies, and institutions?

- How do these policies, strategies, and institutions turn ambitions into actions?

\section{Methods}

This study employed three methods, namely 1) adopting the frameworks developed by the OECD [20] and European Environment Agency (EEA) [21] for evaluating EPI in policies, strategies, and institutions; 2) reviewing six policies, three strategies (see the lists in Table 2) and other relevant documents; and 3) conducting the key informant interviews with the mid- and junior-level officers of the Ministry of Agriculture (MoA), the Department of Agricultural Extension (DAE), and the Bangladesh Agricultural Research Council (BARC) through phone and consultation of the institution's website. The framework developed by the EEA was applied for exam-

Table 1. Selected recently formulated pertinent policy instruments in Bangladesh*

\begin{tabular}{|c|c|c|}
\hline Agriculture $^{* * *}$ & Environment & Governance \\
\hline $\begin{array}{l}\text { - } \quad \text { The Pesticides Act } 2009 \\
\text { - Fertilizer dealer appointment and fertilizer } \\
\text { distribution policy (Amendment) 2009 } \\
\text { - Fertilizer Management Act (Amendment) } \\
2009 \\
\text { - Nursery Guidelines } 2008 \\
\text { - The national Agriculture Award Fund } 2009 \\
\text { - Plant-Quarantine Act } 2011 \\
\text { - Human Resource Development Plan2025 } \\
\text { - Agricultural Research Vision2030 and } \\
\text { Beyond }\end{array}$ & $\begin{array}{ll}\text { - } & \text { Climate Resistant Variety and } \\
\text { Technology Development Rules } 2010 \\
\text { - National Biodiversity Strategy \& Action } \\
\text { Plan } 2004 \\
\text { - Integrated Coastal Zone Management } \\
\text { Plan 2005 } \\
\text { - National Adaptation Plan of Action } 2005 \\
\text { (updated 2009) } \\
\text { - Bangladesh Climate Change Trust Fund } \\
\text { - Act 2010 } \\
\text { - } \quad \text { Revised National Conservation Act } 2010 \\
\text { Environment Courts Act } 2010\end{array}$ & $\begin{array}{ll}\text { - } & \text { Sixth Five-Year Plan 2011-2015 } \\
\text { - } & \text { Public Administration Reform Road } \\
& \text { Map 2010-2014 } \\
\text { - } & \text { National Strategy for Accelerated } \\
& \text { Poverty Reduction-II 2009-2011 } \\
\text { - } & \text { Right to Information Act 2009 } \\
\text { - } & \text { Unlocking the Potential: National } \\
& \text { Strategy for Accelerated Poverty } \\
& \text { Reduction 2005 }\end{array}$ \\
\hline
\end{tabular}

Source: Concern Ministries and [8]; ${ }^{*}$ These policy instruments are different from the reviewed policies and strategies; ${ }^{* *}$ MoA played the leading role in preparing these policies, rules, and regulations. 
ining sectoral policy integration. Taking research limitations into account, only the three core agricultural institutions mentioned above were collectively considered as the agricultural sector. Annual reports, project reports, newsletters, journal articles, books, and research reports were reviewed to understand the actual provision, governance structure, and financial conditions of the institutions to turning objectives into actions of sustainable agri-environmental development.

\section{Results}

\subsection{EPI in Sustainability Discourse}

The integration of environmental concerns into other policy areas, namely agriculture and transport has been referred to as EPI. EPI is regarded as one of the most powerful concepts in the environmental policy discourse in the late twentieth century [22] and a central element of the transition to sustainability [23]. The concept of EPI has emerged after the publication of the "Brundtland report", was enhanced by the "Agenda 21", and subsequently evolved through the European Union and OECD. Although EPI is recognized as a part and parcel of SD, it conceptual clarifications and concrete applications are not directed in the same line. To date, detailed country-specific research on EPI remains very scarce [24]. Primarily, two reasons were found for not applying EPI against its aspirations: 1) environmental concerns are routinely overridden by the socio-economic issue in developing countries, and 2) the concept of EPI has several connotations and interpretations, and little agreement in both academic and policy-making circles.

\subsection{Methods and Evaluation of EPI in Policies and Strategies}

Consistent with the ambiguity and vagueness of EPI conceptualization, i.e. EPI as a process, output or outcome there is a lack of established methods for evaluating EPI. Even the Commission of the European Communities noted that there is no well accepted framework for evaluating EPI [21]. Although few evaluation frameworks were proposed and applied by the researchers [25], those were country-based EPI evaluation, and not applicable for examining EPI of sectoral policies and strategies. Collier [26] proposed that integration be done at three stages in the policymaking process, namely integration of objectives in policy formulation, translation into policy measures (i.e. flexibility), and analysis of different perspectives (e.g. equitability) on EPI implementation by the agencies. With the lessons learned from the explanation of Collier on policy integration, and the operational criteria for policy evaluation framed by the OECD Agriculture Ministers in 1998 [20], five criteria were adopted for examining the EPI of the policies and strategies (Table 2). These criteria fairly corresponds to 1 ) the criteria (e.g. capacity) used by Ross [27] for examining EPI in Australia, and 2) the forms (e.g. institutional) of integration documented by Eggenberger and Partidario [28]. Definition and meaning of the criteria are given below:

- Transparent refers to what extent objectives are identifiable for fostering agri-environmental sustainability.

- Targeted refers to specific outcome or result of the policies and strategies.

- Tailored implies closely fitted to provide support only for identifiable objectives.

- Flexible refers to careful plan for responding to changing objectives and priorities.

- Equitable signifies the provision and planning for providing services to growers, irrespective of their categories, groups, gender, and regions.

\subsection{EPI in Institutions: An Analysis}

The EEA framework has focused on six areas. Table 3 presents the conceptual meaning of the focused areas, which will guide the further explanation of EPI of the institutions.

\subsubsection{Political Commitment and Strategic Vision}

As mentioned earlier, the pursuit of SD is a constitutional obligation. The top-level commitment for secotral sustainability is reflected in the recently published documents such as Rio + 20: National Report on Sustainable Development [8]. The vision, mission, objectives of DAE, BARC, and MoA were highly consistent with the path to the promotion of sustainable development (SD). Specifically, the DAE Strategic Plan for 1999-2002 and 20022006 stated that the core function of the plan is to "increase agricultural productivity and facilitate sustainable agriculture (SA) and environmental management”. However, the second plan reviewed the first plan and stated that the Strategic Plan for 1999-2002 could not be achieved due to its highly ambitious nature and numerous objectives. The revision report also mentioned that other barriers such as inadequate monitoring by the EPICC (Extension Policy Implementation Co-ordination Committee) and insufficient DAE leadership. Moreover, in the vision paper, BARC [7] recognized that the environmental issue on farming production is a major challenge and underscored the significance of conducting more research on the declining and degrading land and water resources for promoting SA.

\subsubsection{Administrative Culture and Practices}

To date, environmental issues in the agricultural sector were only discussed at the ministerial level; it can be 
Table 2. Environmental policy integration in the selected policies and strategies.

\begin{tabular}{|c|c|c|c|c|c|}
\hline & Transparent & Targeted & Tailored & Flexible & Equitable \\
\hline $\begin{array}{l}\text { National Agriculture } \\
\text { Policy (NAP) } 2010\end{array}$ & $\begin{array}{l}\text { The sustainability of } \\
\text { agri-environmental } \\
\text { issue explicitly stated }\end{array}$ & $\begin{array}{l}\text { Obtaining sustainable } \\
\text { growth of agriculture }\end{array}$ & $\begin{array}{l}\text { Tailored, initiatives } \\
\text { are needed to overcome } \\
\text { institutional and } \\
\text { resources problems }\end{array}$ & $\begin{array}{l}\text { Flexible due to } \\
\text { coving several } \\
\text { significant issues, } \\
\text { e.g. feminization } \\
\text { of agriculture }\end{array}$ & $\begin{array}{l}\text { Equity issues } \\
\text { properly } \\
\text { addressed }\end{array}$ \\
\hline $\begin{array}{l}\text { New Agricultural } \\
\text { Extension Policy } \\
1996\end{array}$ & $\begin{array}{l}\text { Poorly addressed and } \\
\text { received the least } \\
\text { significance. }\end{array}$ & $\begin{array}{l}\text { Providing needs-based } \\
\text { agricultural advisory } \\
\text { services }\end{array}$ & $\begin{array}{l}\text { Promoting strategies } \\
\text { and mechanisms but } \\
\text { perceives inadequate. }\end{array}$ & $\begin{array}{l}\text { Little flexible due to } \\
\text { poorly covering } \\
\text { agri-environmental issue }\end{array}$ & $\begin{array}{l}\text { Equitable, e.g. } \\
\text { extension } \\
\text { services for all }\end{array}$ \\
\hline $\begin{array}{l}\text { National IPM } \\
\text { Policy } 2002\end{array}$ & $\begin{array}{l}\text { Explicitly stated that } \\
\text { the objective of } \\
\text { producing healthy } \\
\text { crops }\end{array}$ & $\begin{array}{l}\text { Improving the } \\
\text { environment and } \\
\text { community health. }\end{array}$ & $\begin{array}{l}\text { Adopting feasible } \\
\text { strategies and } \\
\text { institutional set-up }\end{array}$ & $\begin{array}{l}\text { Flexible for } \\
\text { agri-environmental } \\
\text { management }\end{array}$ & $\begin{array}{l}\text { Fairly equitable, } \\
\text { no planning for } \\
\text { share-croppers. }\end{array}$ \\
\hline $\begin{array}{l}\text { Integrated } \\
\text { Small-Scale } \\
\text { Irrigation } \\
\text { Polic } 2011\end{array}$ & $\begin{array}{l}\text { The environmental } \\
\text { sustainability issue } \\
\text { clearly addressed }\end{array}$ & $\begin{array}{l}\text { Ensuring proper and } \\
\text { optimum use of } \\
\text { surface and } \\
\text { ground-water water. }\end{array}$ & $\begin{array}{l}\text { Encouraging bottom-up } \\
\text { approach for management, } \\
\text { but inadequate infrastructure }\end{array}$ & $\begin{array}{l}\text { Flexible due to } \\
\text { addressing important } \\
\text { issue, e.g. irrigation } \\
\text { management in Haor }\end{array}$ & $\begin{array}{l}\text { Clearly } \\
\text { addressed } \\
\text { equity issues, } \\
\text { smallholders } \\
\text { receive priority }\end{array}$ \\
\hline $\begin{array}{l}\text { National Land } \\
\text { use policy } 2001\end{array}$ & $\begin{array}{l}\text { The environmental } \\
\text { sustainability issue } \\
\text { poorly addressed }\end{array}$ & $\begin{array}{l}\text { Reducing land } \\
\text { declination }\end{array}$ & $\begin{array}{l}\text { Perceiving insufficient } \\
\text { due to procedural and } \\
\text { institutional shortfalls }\end{array}$ & $\begin{array}{l}\text { Not flexible, } \\
\text { revamping } \\
\text { is indispensable }\end{array}$ & $\begin{array}{l}\text { Poorly } \\
\text { addressed } \\
\text { equity issues }\end{array}$ \\
\hline $\begin{array}{l}\text { National Water } \\
\text { Policy } 1999\end{array}$ & $\begin{array}{l}\text { Clearly illustrated the } \\
\text { sustainability of water } \\
\text { resources. }\end{array}$ & $\begin{array}{l}\text { Promoting efficient } \\
\text { and equitable water } \\
\text { management }\end{array}$ & $\begin{array}{l}\text { Tailored, feasible } \\
\text { implementation } \\
\text { strategies are needed }\end{array}$ & $\begin{array}{l}\text { Very flexible due to } \\
\text { its decentralized and } \\
\text { democratic nature }\end{array}$ & $\begin{array}{l}\text { Adequately stated } \\
\text { equity issue }\end{array}$ \\
\hline $\begin{array}{l}\text { DAE Strategic } \\
\text { Plan 2002-2006 }\end{array}$ & $\begin{array}{l}\text { Not explicitly stated } \\
\text { rather laid emphasis on } \\
\text { increasing productivity }\end{array}$ & $\begin{array}{l}\text { Supporting other } \\
\text { policy frameworks, } \\
\text { including NAP }\end{array}$ & $\begin{array}{l}\text { Tailored, social capacity } \\
\text { building initiatives are } \\
\text { needed to enhance }\end{array}$ & $\begin{array}{l}\text { Little flexible because } \\
\text { of centralized decision } \\
\text { making procedure }\end{array}$ & $\begin{array}{l}\text { Inadequately } \\
\text { addressed }\end{array}$ \\
\hline $\begin{array}{l}\text { National Sustainable } \\
\text { Development (SD) } \\
\text { Strategy } 2008\end{array}$ & $\begin{array}{l}\text { Clearly addressed } \\
\text { environmental } \\
\text { protection of different } \\
\text { sectors }\end{array}$ & $\begin{array}{l}\text { Implementing SD } \\
\text { by } 2030\end{array}$ & $\begin{array}{l}\text { Tailored enough to achieve } \\
\text { SD, but initiative for proper } \\
\text { implementations are crucial }\end{array}$ & $\begin{array}{l}\text { Very flexible due to } \\
\text { decentralization of } \\
\text { budget management }\end{array}$ & $\begin{array}{l}\text { Equity is a } \\
\text { normative } \\
\text { feature } \\
\text { of this strategy }\end{array}$ \\
\hline $\begin{array}{l}\text { Bangladesh Climate } \\
\text { Change Strategy and } \\
\text { Action Plan } 2008\end{array}$ & $\begin{array}{l}\text { Broadly addressed } \\
\text { environmental } \\
\text { management and } \\
\text { climate change issue }\end{array}$ & $\begin{array}{l}\text { Minimizing the } \\
\text { adverse impacts } \\
\text { of climate change }\end{array}$ & $\begin{array}{l}\text { Tailored, SD of the country } \\
\text { largely depends on } \\
\text { implementation of this plan }\end{array}$ & $\begin{array}{l}\text { Very flexible because } \\
\text { of the mechanisms for } \\
\text { technology generation } \\
\text { and finance }\end{array}$ & $\begin{array}{l}\text { Adequately } \\
\text { addressed } \\
\text { equity issues. }\end{array}$ \\
\hline
\end{tabular}

${ }^{*}$ Haor refers to a saucer shaped large water body formed between the levees of rivers.

Table 3. Meaning of the focused area of the EPI evaluation framework.

\begin{tabular}{ll}
\hline Focused area & Logic \\
\hline $\begin{array}{l}\text { Political commitment and } \\
\text { strategic vision }\end{array}$ & $\begin{array}{l}\text { A sector is environmentally sustainable to the extent that it has high level political commitment, ranging from } \\
\text { public statements to legal texts and to the extent which has overarching objectives and plans. }\end{array}$ \\
$\begin{array}{l}\text { Administrative culture and } \\
\text { practices }\end{array}$ & $\begin{array}{l}\text { A sector is environmentally sustainable to the extent that it reorients management regime that foster } \\
\text { environmental responsibilities and values, and enhances communication and coordination across sectors. }\end{array}$ \\
$\begin{array}{l}\text { Policy design and adoption: } \\
\text { assessment and consultation }\end{array}$ & $\begin{array}{l}\text { A sector is environmentally sustainable if it applies various tools (ex-ante assessment) or systems in decision } \\
\text { making, and incorporates public engagement and expert consultations in policy designing. }\end{array}$ \\
$\begin{array}{l}\text { Implementation: use of policy } \\
\text { instruments }\end{array}$ & $\begin{array}{l}\text { A sector is environmentally sustainable if it deploys feasible financial assistance, market-based and } \\
\text { environmental instrument, besides traditional command and control instruments. }\end{array}$ \\
$\begin{array}{l}\text { Monitoring and learning from } \\
\text { experience }\end{array}$ & $\begin{array}{l}\text { A sector is environmentally sustainable to the extent that it conducts monitoring, reporting, and evaluation } \\
\text { (ex-post analysis) of progress and gather factual information for further strategy formulating. }\end{array}$ \\
$\begin{array}{l}\text { Trends in drivers, pressures, } \\
\text { changes, environmental impacts }\end{array}$ & $\begin{array}{l}\text { A sector is environmentally sustainable if the levels of sector's socio-economic impacts are low enough to } \\
\text { meet its own environmental targets and objectives. }\end{array}$ \\
\hline
\end{tabular}

stated that no strategic relations were available in terms of collaboration between the MoA and the Ministry of
Environment and Forest (MoEF) on agri-environment issue. MoA published its two-year (2009-2010) success 
and failure report; no achievement related to the agrienvironment issue was found in this report. Moreover, the Plant Protection Wing (i.e. department) of DAE stated that "monitoring and assessing the environmental impact of pesticide use" is one of their major responsebilities; however, no such plans or organizational setup formulated for this task. In fact, MoA [29] acknowledged that environmental considerations have not been getting the attention they deserved in the agriculture sector. There were some other initiatives taken by the MoA and DAE to keep the environmental impact at a minimum in farmers' field such as including environmentalists in all fertilizer management bodies, particularly in the National Fertilizer Standardization Committee, with a view to initiate mass awareness programs on health hazards that come from the excessive use of agrochemicals. In addition, BARC has taken cross-cutting initiatives for environmental management, for instance, by introducing the integration of environmental considerations into the long-term National Agricultural Technology Project (NATP) in agricultural research, extension, and value chain development (Table 4). Its overarching environmental management framework for environmental screening and monitoring was an important step for achieving agri-environmental sustainability.

\subsubsection{Policy Design and Adoption: Assessment and Consultation}

Although the government designed several policies (Table 1), their implementation was found to be one of the major challenges of achieving SA. Some of the shortcomings are in the policy process, for instance, most of agricultural policy documents were based on notional ideas, and lacked empirical assessment and wider consultations of stakeholders [18]. The World Bank [15] points out that policy and institutional reforms were needed to reorient the national agricultural research and extension systems, mainstreaming partnership with organizations to tackle the future challenges. Moreover, a substantial tension observed between the bureaucrats and politicians, and traditionally, the bureaucrat dominates in the policy making process and therefore, implementation management was founded on a strong power base that was largely dysfunctional [30]. In contrast, politicians had relatively little experience in democratic politics and even less in policy making. Policy formulation was completely capital-based, which had little connection with the rural communities. Consequently, a huge ambiguity in policy objectives and its negative impacts were observed at the district-level [31]. In particular, researchers reported that framing a broader policy context (i.e., grower's needs, scientific potential, and the national and international priorities) and revitalizing of several agricultural policies are essential for transitioning to sustainability such as land policy [15], fertilizers and irrigation subsidy policy [18], and agricultural extension policy [32].

\subsubsection{Implementation: Use of Policy Instruments}

In terms of policy implementation, the agricultural sector was observed relatively weak due to insufficient decentralized local governance [31], capacity of MoA [18], demand-driven institutional frameworks [33], and policy support from the top level [7]. Gill et al. [34] states that how the public agricultural advisory system suffers from several malaises, for instance, agricultural training institutes within the DAE were not functioning well in relation with the field level extension services. Islam et al. [33] explains why the donor-supported extension reforms were not sustainable. Still, the government provides the financial incentives to $\mathrm{N}_{2}$ fertilizer, while India and China shifted their subsidy plan from $\mathrm{N}_{2}$ fertilizer towards a better mix of nutrients [35] and guided the agricultural technology choices [36], respectively. However, the present government has taken good initiatives for implementing policies beyond command and control strategies such as popularizing "urea deep placement (UDP)" technology in the irrigated rice field, saving about 50\% $60 \%$ urea use and increasing yield by almost 1 ton/ha [37], and implementing the IRRI developed water saving technology "alternative-wetting and drying (AWD)" that can potentially reduce methane emissions by $48 \%$, compared to continuous flooding in the rice field [38]. Moreover, as a market-based instrument, government introduced incentive for Aus rice (direct seeded or transplanted rice in pre-monsoon season) to restore the lost glory of this rice and amended the fertilizer subsidy policy, emphasizing on non-urea fertilizers such as $\mathrm{P}_{2} \mathrm{O}_{5}$,

Table 4. Environmental issues considered in national agricultural technology project.

\begin{tabular}{lll}
\hline Agricultural Research & Extension & Value Chain \\
\hline Biodiversity loss & Soil degradation & Exotic species \\
Pest infestation & Contamination through pesticides & Biodiversity \\
Arsenic contamination & Decline in soil fertility & Pollution from poultry and dairy farms \\
High input requiring varieties & Soil salinity & \\
Drought & Pest infestation & \\
& Health hazard from agro-chemical handling & \\
\hline
\end{tabular}


$\mathrm{K}_{2} \mathrm{O}$. The government used other instruments, namely launching spatial planning, e.g. Haor Master Plan 20122032; formulating rules of climate resistant short-duration crop varieties and technology development; and introducing environmental court in all districts, expecting to have knock-on effects in fostering SA and development.

\subsubsection{Monitoring and Learning from Experience}

Neither the National Agriculture Policy (NAP) nor the National Agricultural Extension Policy (NAEP) has anything significant to say about environmental monitoring, reporting, and evaluation. NAEP included "strengthening monitoring and evaluation” as a last pillar (out of 26) and in the text, this policy merely states that participatory monitoring and evaluation is to be introduced at all levels of extension initiatives [39]. Moreover, the Planning and Evaluation Wing of the DAE reports superficial responsibilities of monitoring and evaluation in the project implementation process. However, in both cases, there were no specific targets, tools or indicators, and plans for monitoring. Overall, the institutional capacity of the agricultural sector for monitoring and evaluation measures identified still very weak. Gill et al. [34] also found similar shortcomings in agricultural institutions.

The MoEF and Department of Environment (DoE) has an important responsibility for working with other ministries to maintain and improve the environmental management measures of development programs. Studies $[14,15]$ reported that both these institutions suffered resource problems, particularly shortage of budget and inadequate manpower. Similarly, Ahammed and Harvey [40] stated that a substantial lack of coordination was observed between the MoEF and line ministries. Although providing environmental clearance of public sector projects is ad hoc, there were no structured guidelines for dealing with the environmental assessment of the non-industrial projects by the DoE. Even line ministries do not have adequate legal proceedings if the DoE does not address the environmental assessment timely. Moreover, high level committees such as the National Environment Council headed by the Prime Minister, the Executive Committee of National Environment Council headed by the Minister of MoEF, and Divisional Environment Committee chaired by the Commissioner are yet to be fully functional. Overly centralized environmental governance is a great weakness of the country with practically no institutional structure at the sub-district and village levels.

The country enacted environmental impact assessment (EIA) rules in 1997. In practice, EIA application was non-existent in most of the sectors, and implementation of EIA was largely dependent on the requirements of donor agencies [41]. Surprisingly, recently published two key governmental documents, namely "National Sustainable Development Strategy" [42] and "Rio + 20: National Report on Sustainable Development" [8], which say nothing significant on the application of EIA. However, the Sixth Five-Year Plan (2011-2015) emphasized on the drafting of EIA guidelines for all sectors under the Environment Conservation Act 1995 and effective enforcement of EIA [1]. Recognizing EIA as a legal requirement, "Vision 2021" illustrated its institutionalizetion and effective implementation, stating the present shortcomings of EPI such as lack of legislative control over the EIA and future strategies, e.g. ensuring civil societies and NGOs participation [6].

\subsubsection{Trends in Drivers, Pressures, Changes, and Environmental Impacts}

Overpopulation is the biggest driver of adverse environmental impacts in Bangladesh, with a growth rate of $1.32 \%$ (in 2011). Due to the need to feed the burgeoning population, the country is largely bound to produce more food crops, intensifying the use of agro-chemicals, irrigation, and other resources. For instance, from 1979 to 2001, the annual rate of an increase of the irrigated area over 4\% [29]. External-input-based intensification raised environmental concerns such as soil salinity, compactness, acidity, water logging, and drainage impedance [43]. Farmers faced enormous challenges of shortage of natural resources, and most of the country's soils suffered from organic matter depletion and contained less than $1 \%-1.7 \%$ of organic matters although a good soil should have at least $2.5 \%$ organic matter [7]. Erosion of agro-biodiversity, deterioration of water quality, pervasive rural poverty, rice price falls, and speculation of food prices exacerbated the growing concerns, indicating that the present rice production trends were not ecologically sound, profitable, and nor socially responsible $[44,45]$. Moreover, agriculture is already being impacted by climate change, by changing and shifting pattern of rainfalls, intensive flooding, and droughts [8].

\subsection{Turning Policies Ambitions into Actions: A Stocktaking}

\subsubsection{National Agriculture Policy (NAP)}

NAP has four objectives and an overarching ambition of "creating an enabling environment for sustainable growth of agriculture”, which is envisaged to turn into actions by improving nine components such as research and development. NAP indentified several plans and programs, for instance, creating agri-business opportunities and promoting balanced fertilizers. NAP applied various instruments, e.g. cash incentives and subsidies to promote these programs. Moreover, this policy underscored forging the partnership between government organization 
(GOs), NGOs, private organization (POs), and donor organizations (DOs) in research, human resource development, and modernization of agricultural advisory services. Relatively, NAP emphasized institutional capacity building in different areas: improving governance of the institutions, decentralizing extension activities, and providing access to institutional credit.

NAP stated their intension to restrict the conversion of agricultural land for non agricultural purposes, but how? Clear guidelines are required. Land fragmentation is a chronic problem. The land person ratio is one of the lowest in the world, estimated at 0.12 ha [46], and a $1 \%$ increase in land fragmentation reduced rice output by $0.05 \%$ [47]. However, NAP did not address this significant issue. Riverbank erosion is a perennial problem for this country, and NAP also recognized this problem as a potential threat to the agricultural sector [48]. About 500 $\mathrm{km}$ of riverbank face severe problems related to erosion, and annually it affects about a million people [14]. However, NAP did not address this issue as well.

\subsubsection{New Agricultural Extension Policy (NAEP)}

NAEP was a joined effort by the GOs, NGOs, and POs, stipulating a goal of providing efficient and effective agricultural advisory services to growers, comprising of 11 components and action plans, including devolution of responsibilities and coordination of extension activities from the national to local level. The application of participatory methods (e.g. PRA and RRA) in determining agricultural problems and the provision of three-stage institutional mechanisms, namely national, regional, and district/sub-district for establishing a free flow of information between the extension agents and research institutes indicated fairly a good strategy for extension services. Moreover, the consideration of five foundations, for example, training, collaboration, monitoring for the implementation strategy might serve as an appropriate point of departure. NAEP theoretically included environmental integration into the policy, and proposed to apply EIA for monitoring the impact of agricultural practices. However, the actual picture of the extension services at the field level was a bit different. Researchers $[32,34]$ have criticized the effectiveness of existing agricultural advisory services due to its lacking of availability and accountability, and recommended reorienting and revitalizing this service with a new knowledge base, through emerging technologies and methods to harness SA development.

\subsubsection{National IPM Policy (NIP)}

In 1981, IPM activities first started in Bangladesh, and by the end of 2001, it received considerable popularity across the country. NIP has five key components with a vision of enabling farmers to grow healthy crops, while improving the environment and community health. There were many good features in this policy document such as its adequate presentation of the plan for implementation, which is probably the most difficult, demanding, and critical stage for a policy process [49]. NIP presented the strategies for implementation and institutional set-up of the IPM program in a detailed manner (more than onethird of the document). Moreover, the action plan of human resource development was visionary and contemporary in terms of the promotion of gender-specific training courses and incorporation of modern practical IPM in the curricula of schools, colleges, and universities. However, it failed to include the appropriate mix of instruments, e.g. financial to support poor farmers for the adoption of IPM.

\subsubsection{Integrated Small-Scale Irrigation Policy (ISSIP)} ISSIP is a recent initiative of MoA that has 21 components and a main objective: to ensure proper and maximum utilization of surface and groundwater for crop production. Adopting a bottom-up decision-making process, and providing statutory structure and institutional policy were some of the major attributes of this policy. Moreover, stakeholder involvement in sub-district and district level committees, and planning for water resource management based on geographic variations was an appropriate strategy to achieve objectives. However, ISSIP has been lacking in 1) addressing specific strategy to mitigate ground water pollution in the "Barind Track"-a recognized irrigated rice producing region of the country, and 2) drawing explicit action plans and setting targets for the expansion of irrigation coverage in hilly areas. Although climate change is a pressing issue, MoA did not consider its impact adequately in the decision making process on irrigation management.

\subsubsection{National Land Use Policy (NLUP)}

NLUP has nine objectives such as reducing the overwhelming trends of declination in agricultural land, and 28 key components. It does not stipulate implementation strategy nor provide the adequate institutional structure at the district and sub-district levels. Moreover, NLUP does not provide any indications about how to handle the issue of "land grabbing", including riverine islands and waterbodies. Moreover, it is essential to clarify and provide guidance about the right of the indigenous community, women, and the youth on land. A report on the feasibility of NLUP was prepared by Barkat et al. [50] and captured the whole gamut of shortcomings of the NLUP, and providing a detailed proposal for revamping. Although the issue of creating mass public awareness for policy implementation was appropriately addressed by the NLUP; overall, NLUP failed to address how to materialize its objectives into actions. 


\subsubsection{National Water Policy (NWP)}

NWP consists of six objectives and 16 components. The processes of policy making (e.g. involving local and foreign experts), adopting good governance (participatory decision making), enunciating a policy framework (adopting a coordination of existing and community-based institutions), and outlining a legislative framework gave this policy document a decentralized and democratic nature that helped to implement it properly as well as manage the country's water resources in a comprehensive, integrated, and equitable manner. Moreover, NWP significantly laid emphasis on applying EIA, other analytical procedures and evaluation methods, e.g. risk analysis, and the guidelines for people's participation, particularly women in project planning and management. Similarly, this policy proposed the application of several marketbased, environmental management, and financial instruments such as the introduction of positive financial incentives, taxes, and charges to internalize environmental externalities. However, it was found that NWP neither explicitly consider the issue of climate change, nor the arsenic issue.

\subsection{Turning Strategies Ambitions into Actions: A Stocktaking}

\subsubsection{DAE Strategic Plan 2002-2006 (DSP)}

DSP has five objectives that were designed to support several policy frameworks, including NAP and NAEP. The main input for this plan came from the experience and learning from the preceding DAE Strategic Plan (1999-2002). DSP applied a range of programs such as providing practical knowledge on crop and non-crop activities, improving soil health, and diversifying crops. Similarly, this strategy used instruments, namely input and credit support as well as community-based natural resource management. DSP adopted coordination, cooperation, and collaboration with the local governments, NGOs, and POs. Leadership development, use of mass media, and unified monitoring and evaluation systems were used as institutional capacity building strategies. Overall, it can be stated that DSP's activities were more suitable to achieve its objectives rather than broadly support the other policy frameworks.

\subsubsection{National Sustainable Development Strategy (NSDS)}

The preparation of the NSDS is a bold step towards SD. NSDS identified four strategic priority areas along with three cross-cutting areas, namely good governance, human resource development, and gender for achieving an overarching vision of the NSDS. Four challenges were determined as well as four strategies were set out for the promotion of $\mathrm{SD}$, for instance, enhancing institutional capacity and creating a knowledge base for SD.

This strategy adopted nine formulation principles. The systematic procedures of the NSDS formulation augmented the scope for careful planning and preparation of the institutional framework for implementation. The composition of members of Sustainable Development Monitoring Council (SDMC) and Sustainable Development Board (SDB) as well as the assigned role clarifications of the SDMC and the terms of references of the SDB are a conspicuous instance of good governance. Moreover, the proposals for preparing a separate budget to carry out its mandates and institutional structure under the MoEF (assumed the MoEF not being capable of providing necessary secretarial support to the council) are two commendable features of the NSDS. However, beyond the national level, the provision of a regional, at least divisional level institutional framework would bear more meaning of decentralization and devolution of power, which is an indispensable attribute of SD [51].

\subsubsection{Bangladesh Climate Change Strategy and Action Plan (BCCSAP)}

BCCSAP comprises six pillars, for instance, food security and infrastructure development. This plan was an integral part of the country's development policies, including the Sixth Five-Year Plan. Climate change requires an integrated approach; therefore, one of the central aims of this plan is to develop an overarching climate governance structure, consisting of ministries, agencies, NGOs, civil societies, and other stakeholders.

Moreover, climate policy integration in governance is an essential aspect, which is adequately addressed by the BCCSAP, for example, to date eight ministries have set up climate change unit [52]. Several top and mid-level committees have been established, including the National Steering Committee on Climate Change. BCCSAP underscored that the financial mechanisms and technologies generation were the vital means to overcome adaptation and mitigation, and has formulated several short, mid, and long-term strategies. Recently, the government has established a National Climate Change Fund, with an initial capitalization of $\$ 45$ million, later raised to $\$ 100$ million, to be used for adaptation [52]. Overall, BCCSAP addresses how to create mass awareness, build public capacity, and develop a resilient nation to meet the future climate challenges.

\subsection{Turning Institution's Ambitions into Actions: A Stocktaking}

\subsubsection{Department of Agricultural Extension (DAE)}

The aim of the DAE is to promote SA and socio-economic development by providing needs-based agricultural extension services to farmers. One of the main at- 
tributes of the DAE was to build the partnerships in the form of interaction, cooperation, and collaboration with the GOs, NGOs, POs, and DOs; for instance, with the collaboration of FAO DAE successfully established IPM in Bangladesh. DAE has been conducting many projects on crop diversification, integrated agricultural productivity, and adaptation of climate change with other organizations.

However, DAE faced several problems such as shortage of adequate funding, skilled manpower, and appropriate extension approach. These problems have been compounded by the centralized decision making system and influence from politics and bureaucrats in the administration and management. Perhaps, the country's present ratio of extension agent to farmer (1:900) is the highest in the world. Moreover, in terms of providing services to the people, public extension is facing a silent competition with NGOs, POs (e.g. seed companies), and third sector (e.g. farmers' organizations). Consequently, this service has lost its traditional reliability of the farmers because of unavailability, ineffectiveness, and lack of monitoring and accountability of the services [19]. Institutional shortcomings of the DAE have also been observed, for instance, lack of separate working guidelines of the wings and weaker planning and evaluation wing. Nevertheless, there was no option to indicate that DAE is not progressing in terms of providing information and services to the grass root-level farmers and contributing to the national mandates; however, probably it failed to keep pace with the challenges of declining and degrading natural resources, wider yield gaps, and climate change.

\subsubsection{Bangladesh Agricultural Research Council (BARC)}

BARC is an umbrella institution under which the entire agricultural research effort is coordinated. BARC has a professional audit cell and institutional set-up that successively administered the preparation of the vision document and national agricultural research plan. The demand-driven technology generation (e.g. post harvest technologies), documentation and dissemination of research outputs, and frequent human resource development programs for agricultural professionals indicate fairly well the level of institutional capacities of the BARC.

BARC has been given many overarching functions without clear focus. Shortages of funding and inadequate physical facilities were found to be the major problems of BARC. The research effort for monitoring and coordination of the NARS through BARC remained weak as ever [19]. The agricultural research institutes (ARIs) and BARC have no clear guidelines for transparent financial management. In terms of institutional capacity and human skills, BARC was weaker than the ARIs; therefore, it has been facing hurdles in administering and monitoring the ARIs. The Technology Transfer and Monitoring Unit (TTMU) of the BARC was established to facilitate the linkages with stakeholders, but TTMU had neither virtual functions nor adequate financial and human resources. However, the inclusion of the "Environmental Management Framework" and the "Social Management Framework" in the NATP was a recent initiative of the BARC and MoA, which was a stepping-stone to fostering agri-environmental sustainability.

\subsubsection{Ministry of Agriculture (MoA)}

The main aim of the MoA is to formulate agricultural policies, plans, regulations, and acts to achieve sustainable agriculture development and food sufficiency as well as to provide support to 18 agencies. MoA was one of the responsible ministries, which only published her achievements and failures report, as well as an action plan for the implementation of "Vision 2021", an important strategic articulation of the development goals proposed by the present government. In terms of policy instrument preparation, this ministry has played a very significant role (see the list of recent policies under the agriculture category of Table 1). Moreover, the introducetion of "Growers Agricultural Card" for fuel incentives, "Aus Rehabilitation" for Aus rice development, and the formulation of "Climate Resistant Variety and Technology Development Rules" are some of the recent significant initiatives taken by the MoA. However, it has also been facing numerous challenges such as shortage of manpower, physical facilities, and funding as well as excessive bureaucracy $[19,53]$.

\section{Discussion and Implications}

Table 2 demonstrates a clear picture of the reflection of the EPI in policies and strategies. From the findings of this table, it can be said that most of the policies and strategies addressed the EPI concept such as National Water Policy, which had ground water management as a main identifiable objective and tailored attributes, e.g. institutional policy to support for achieving the objectives. The flexibility, namely decentralization of power and the equitability characteristics of this policy has created a favorable environment to obtain these objectives. An inadequate reflection of the EPI was observed in the National Land Use Policy. The shortcomings of the land use policy are well understood by the government, and it was reported that this policy is being formulated.

EPI in the institutions faced many obstacles. First, shortage of manpower and inadequate funding was the major barriers, and these problems have been accompanied by the lack of physical facilities and excessive bureaucratic technicalities. Second, the governance systems 
were capital-centered, which had a poor relation with the local level that created problems in policy implementation. And third, there is a very poor administrative culture in terms of collaboration and cooperation regarding the practical environmental management issues. $\mathrm{Al}$ though constitutional and political commitment for SD is noticeable, only poverty alleviation and achieving food security were prominent at the local administrative level. Therefore, a strategic gap of priority in the development agenda was created. This phenomenon can be explained by two present conditions: fulfilling the basic needs were noted to be a primary concern of the people and fragmenting relations in terms of agenda setting and policy formulation were observed between the top and root level.

In the case of turning ambitions into actions, institution have encountered the same setbacks faced when integrating environmental concerns in the institutions; for example, DAE has an extended network for extension service throughout the country. However, due to shortage of extension personnel, these services are not available at the farmer's level, and this problem occurred mainly due to the shrinking government budget. In addition, neither the monitoring section of DoE nor the monitoring wing of DAE are instrumentally, financially, or institutionally capable of addressing problems of agri-environment and socio-economic development.

As stated earlier, the translation of policy options is the most critical stage of a policy cycle and its success largely depend on administrative capacity briefly discussed above. Moreover, other institutions and stakeholders' involvement are equally important in this process. Furthermore, appropriateness of policy design and evaluation is important for turning policy objectives to actions. Overall, it was found that 1) most of the policies and strategies have prepared systematically with a fair inclusion of institutional strategy, policy, and framework such as the IPM policy and the National SD Strategy and 2) although the policy and strategy documents were good, taking administrative capacity, the fragile conditions of monitoring and evaluation, as well as exclusion of stakeholders into account, the implementation has often been neglected in practice.

The policy implications are clear. First, policies should emphasize enhancing institutional capacity by fulfilling the vacant posts, building human capital, and improving physical facilities. Additionally, increasing government budget for agricultural institutions, particularly for the Department of Agricultural Extension (DAE) is indispensable. Second, policies geared towards addressing the shortcomings of agricultural advisory services through empirically assessing farmers' extension demands, and according to demand DAE should formulate feasible strategies to improve the quality of extension personnel and services as well as to promote demand-driven partnerships with other organizations. Third, empowerment of BARC is significant to strengthen the national agricultural research capability and quality through facilitateing and integrating the agricultural institutions. And fourth, is to set pragmatic policy implementation strategy by reorienting the monitoring and evaluation bodies, as well as to formulate clear guidelines, legislations, and institutional legal structures for realistic actions, and enhance participation of local institutions from the outset of the policy cycle.

\section{Acknowledgements}

Editorial support from Mr. Olivier Gervais, GCI, YCU and financial support from Yokohama City University (YCU), Yokohama, Japan is gratefully acknowledged.

\section{REFERENCES}

[1] Planning Commission, "Sixth Five-Year Plan FY20112015: Accelerating Growth and Reducing Poverty (Part-1 Strategic Directions and Policy Framework),” Ministry of Planning (MoP), the Government of Bangladesh (GoB), 2011.

[2] BBS (Bangladesh Bureau of Statistics), "Statistical Yearbook of Bangladesh,” BBS Division, MoP, GoB, 2011.

[3] M. Hossain "The Impact of Shallow Tube Wells and Boro Rice on Food Security in Bangladesh,” IFPRI Discussion Paper 00917, IFPRI, 2009.

[4] MEA (Millennium Ecosystem Assessment), "Ecosystems and Well-Being,” Island Press, Washington, D.C., 2005.

[5] J. Kitzes, M. Wackerngel, J. Loh, A. Peller, S. Goldfinger, D. Cheng and K. Tea, "Shrink and Share: Humanity's Present and Future Ecological Footprint," Philosophical Transactions of the Royal Society B, Vol. 363, No. 3, 2008, pp. 467-475. doi:10.1098/rstb.2007.2164

[6] CPD (Centre for Policy Dialogue), "Bangladesh Vision 2021," CPD, Dhaka, 2007.

[7] BARC (Bangladesh Agricultural Research Council), "Research Priorities in Bangladesh Agriculture, Final Draft," Dhaka, 2011.

[8] MoEF (Ministry of Environment and Forest), "Rio + 20: National Report on Sustainable Development,” GoB, 2012.

[9] M. Alauddin and J. Quiggin, “Agricultural Intensification, Irrigation and the Environment in South Asia: Issues and Policy Options,” Ecological Economics, Vol. 65, No. 1, 2008, pp. 111-124. doi:10.1016/j.ecolecon.2007.06.004

[10] M.T. Chowdhury, "Sustainability of Accelerated Rice Production in Bangladesh: Technological Issues and the Environment," Bangladesh Journal of Agricultural Research, Vol. 34, No. 3, 2009, pp. 523-529. doi:10.3329/bjar.v34i3.3979

[11] R. Roy and N. W. Chan, “An Assessment of Agricultural Sustainability Indicators in Bangladesh: Review and Synthesis,” Environmentalist, Vol. 32, No. 1, 2012, pp. 99- 


\section{0. doi:10.1007/s10669-011-9364-3}

[12] R. Roy, N. W. Chan and R. Rainis, "Development of Indicators for Sustainable Rice Farming in Bangladesh: A Case Study with Participative Multi-Stakeholder Involvement,” World Applied Science Journal, Vol. 22, No. 5, 2013, pp. 672-682.

[13] R. Roy, N. W. Chan and R. Rainis, "Development of an Empirical Model of Sustainable Rice Farming: A Case Study from Three Rice-Growing Ecosystems in Bangladesh," American-Eurasian Journal of Agricultural \& Environmental Sciences, Vol. 13, No. 4, 2013, pp. 449-460.

[14] ADB, "Country Environmental Analysis Bangladesh, 3rd Draft,” Asian Development Bank, Dhaka, 2004.

[15] World Bank, "Bangladesh: Country Environmental Analysis,” Bangladesh Development Series Paper No. 12, The World Bank Office, Dhaka, 2006.

[16] A. Jordan and A. Lenschow, "Environmental Policy Integration: A State of the Art Review," Environmental Conservation Police Officers, Vol. 20, No. 3, 2010, pp. 147158. doi:10.1002/eet.539

[17] T. Hák, B. Moldan and A. L. Dahl, "Sustainability Indicators: A Scientific Assessment,” Island Press, Washington, 2007.

[18] M.A.S. Mandal, “A Synthesis of Agricultural Policies in Bangladesh,” Agriculture Sector Review, Ministry of Agriculture (MoA), Dhaka, 2006.

[19] Agriculture Sector Review, "Actionable Policy Brief and Resource Implications: Volume I,” MoA, Dhaka, 2006.

[20] OECD, "Agricultural Policies in OECD Countries: At a Glance,” OECD, Paris, 2004.

[21] EEA (European Environment Agency), "Environmental Policy Integration in Europe: State of Play and an Evaluative Framework," Technical Report, No. 2/2005, EEA, Copenhagen, 2005.

[22] M. Nilsson and K. Eckerberg, "Environmental Policy Integration in Practice,” Earthscan, London, 2007.

[23] A. Jordan, A. "The Governance of Sustainable Development: Taking Stock and Looking Forwards," Environment and Planning C, Vol. 26, No. 1, 2008, pp. 17-33. doi:10.1068/cav6

[24] A. Jordan and A. Lenschow, "Innovation in Environmental Policy? Integrating the Environment for Sustainability,” Cheltenham, Elgar, 2008.

[25] A. Nilsson and A. Persson, "Framework for Analyzing Environmental Policy Integration," Journal of Environmental Policy and Planning, Vol. 5, No. 4, 2010, pp. 333359. doi:10.1080/1523908032000171648

[26] U. Collier, "Energy and Environment in the European Union,” Avebury, Aldershot, 1994.

[27] R. Ross, “Australia,” In: A. Jordan and A. Lenschow, Eds., Innovation in Environmental Policy, Cheltenham, Elgar, 2008, pp. 289-310.

[28] M. Eggenberger and M. Partidario, "Development of a Framework to Assist the Integration of Environmental, Social and Economic Issues in Spatial Planning," Impact Assess and Project Appraisal, Vol. 18, No. 3, 2000, pp. 201-207. doi:10.3152/147154600781767448
[29] MoA, "Transformation of Agriculture for Sustainable Development and Poverty Alleviation in Bangladesh: Actionable Policies and Programs,” GoB, 2006.

[30] P. Thornton, “The Formal Institutional Framework of Rural Livelihoods in Bangladesh,” In: K. A. Toufique and C. Turton, Eds., Hands Not Land: How Livelihoods Are Changing in Rural Bangladesh, Bangladesh Institute of Development Studies (BIDS) Publication, Dhaka, 2002.

[31] H. Z. Rahman, "Re-Thinking Local Governance: Towards Livelihoods Focus,” In: K. A. Toufique and C. Turton, Eds., Hands Not Land: How Livelihoods Are Changing in rural Bangladesh, BIDS Publication, Dhaka, 2002.

[32] M. Asaduzzaman, C. Ringler, J. Thurlow and S. Alam, "Investing in Crop Agriculture in Bangladesh for Higher Growth and Productivity, and Adaptation to Climate Change,” Bangladesh Food Security Investment Forum, Dhaka, 2010.

[33] M. Islam, D. I. Gray, J. I. Reid, T. C. Kelly and P. D. Kemp, "Beyond Recurrent Costs: An Institutional Analysis of the Unsustainability of Donor-Supported Reforms in Agricultural Extension,” Journal of International Agricultural and Extension Education, Vol. 18, No. 3, 2011, pp. 5-18.

[34] G. Gill, A. Bartlett, E. Huda and T. Begum, “Agriculture Services Innovation Reform Project: End of Project Review Report,” Rural Livelihoods Evaluation Partnership, Dhaka, 2003.

[35] S. P. Anand, J. E. Segal and V. Stiglitz, "Debates on the Measurement of Global Poverty,” Oxford University Press, Oxford, 2010. doi:10.1093/acprof:oso/9780199558032.001.0001

[36] International Fund for Agricultural Development, "Rural Poverty Report 2011,” IFAD, 2010.

[37] Food and Agriculture Organization, “'Climate-Smart’ Agriculture: Policies, Practices and Financing for Food Security, Adaptation and Mitigation,” Rome, 2010.

[38] B. A. M. Bouman, R. M. Lampayan and T. P. Tuong, "Water Management in Irrigated Rice: Coping with Water Scarcity,” IRRI, Los Baños, 2007, 54 p.

[39] MoA, "National Agricultural Extension Policy,” MoA, GoB, 2012, p. 34.

[40] R. Ahammed and N. Harvey, "EIA in Bangladesh: Evaluation of Environmental Impact Assessment Procedures and Practice in Bangladesh,” Impact Assess and Project Appraisal, Vol. 22, No. 1, 2003, pp. 63-78. doi:10.3152/147154604781766102

[41] S. Momtaz, "Environmental Impact Assessment in Bangladesh: A Critical Review," Environmental Impact Assessment Review, Vol. 22, No. 2, 2002, pp. 163-179. doi:10.1016/S0195-9255(01)00106-8

[42] Department of Environment, "National Sustainable Development Strategy Bangladesh,” MoEF, GoB, 2008.

[43] M. Jahiruddin and M. A. Satter, "Agricultural Research Priority: Vision-2030 and beyond, Sub-Sector: Land and Soil Resource Management,” Final Report, BARC, Dhaka, 2010.

[44] S. Shahid and H. Behrawan, "Drought Risks Assessment 
in the Western Part of Bangladesh,” Journal of the International Society for the Prevention and Mitigation of Natural Hazards, Vol. 46, No. 3, 2008, pp. 391-413. doi:10.1007/s11069-007-9191-5

[45] A. Rahman, M. Alam and M. Hossain, "Risks, Vulnerability and Adaptation in Bangladesh," Human Development Report Office Occasional Paper, 2007/13, Dhaka, 2008.

[46] Food and Agriculture Organization, "Supplements to the Report on the 1990 World Census of Agriculture," Statistical Department Series, Rome, 2001.

[47] S. Rahman and M. Rahman, "Impact of Land Fragmentation and Resource Ownership on Productivity and Efficiency: The Case of Rice Producers in Bangladesh,” Land Use Policy, Vol. 26, No. 1, 2008, pp. 95-103.

$$
\text { doi:10.1016/j.landusepol.2008.01.003 }
$$

[48] MoA, “National Agriculture Policy 2010,” MoA, GoB, 2010.

[49] UNDP, "Integrated Policymaking for Sustainable Development: A Reference Manual,” UNDP, Geneva, 2009.

[50] A. Barkat, R. Ara, M. Taheruddin, S. Hoque and N. Islam, “Towards a Feasible Land Use Policy of Bangladesh," Human Development Research Centre, Dhaka, 2007.

[51] B. Dalal-Clayton and S. Bass, "Sustainable Development Strategies: A Resource Book,” OECD, Paris, 2002.

[52] MoEF, "Bangladesh Climate Change Strategy and Action Plan 2008,” GoB, 2009, 94 p.

[53] MoA, "Two Years Achievements of MoA: An Implementation for Vision 2021,” Dhaka, 2011, 22 p. 